\title{
KAJIAN LITERATUR: EFEKTIVITAS PELATIHAN DALAM ORGANISASI
}

\author{
Ubaidillah \\ Dosen Fakultas Ekonomi Universitas Batanghari Jambi
}

\begin{abstract}
This study discusses the role of training effectiveness, in improving employee performance towards the organization, the method used in this study is to look at theoretical theories related to the study of the impact and influence of training effectiveness on employee performance in the organization, the results of this study explain that training is applied to employees can have an effect on improving the ability and competence of employees, so that ultimately can affect the performance of employees in the organization.
\end{abstract}

Key word : effectiveness employee performance

\section{PENDAHULUAN}

Sumber daya manusia merupakan faktor utama dalam sebuah organisasi, jika sebuah organisasi memiliki sumber daya manusia yang unggul maka kinerja organisasi tersebut akan meningkat pula. Usaha meningkatkan kinerja suatu organisasi tidak terlepas dari usaha peningkatan kinerja masing-masing anggotanya. Untuk meningkatkan kinerja masing-masing masing individu tersebut maka diperlukan stimulir, terutama berkaitan erat dengan kebutuhannya. Peningkatan kinerja organisasi akan sangat tergantung dari upaya peningkatan kinerja individu. Salah satu upaya yang dilakukan organisasi dalam meningkatkan kinerja individu adalah memberikan pelatihan. Pelatihan dapat dilaksanakan di dua tempat yaitu pelatihan di tempat kerja (on- the job training) dan di luar tempat kerja (off- the job training). Teknik utama pelatihan di tempat kerja antara lain adalah demonstrasi (praktek menyelesaikan sesuatu dalam rangka meningkatkan skill pegawai), melatih (lebih mengarah pada praktek manajerial dan professional), melatih dengan cara mengerjakan sendiri serta rotasi kerja. Sedangkan pelatihan di luar tempat kerja, teknik pelatihannya antara lain ceramah, studi kasus, permainan peran, grup diskusi, pusat pengembangan, dinamika grup, belajar melalui tindakan, proyek, permainan bisnis, dan pelatihan di tempat terbuka.

Perspektif manajemen sumber daya manusia yang menempatkan pegawai sebagai partner, mempunyai konsekuensi dalam kebutuhan organisasi guna menciptakan pemimpin di setiap tingkatan organisasi lembaga pendidikan. Setiap pegawai harus memiliki karakter pemimpin dan ketrampilan manajerial yang baik. Karenanya, setiap pegawai memerlukan pelatihan dan pengembangan diri untuk meningkatkan kualitas kepemimpinannya. Pelatihan juga diperlukan sebagai bentuk ketanggapan terhadap perkembangan dunia pendidikan pada era sekarang. Lingkungan pendidikan saat ini diwarnai oleh kompetisi yang semakin ketat, meningkatnya tuntutan dan kesadaran untuk pemenuhan lebih banyak kebutuhan pegawai.

\section{Kajian Teoritis}

Oemar Hamalik (2007:10) memgemukakan bahwa pelatihan adalah suatu proses yang meliputi serangkaian tindak (upaya) yang dilaksanakan dengan sengaja dalam bentuk pemberian bantuan kepada tenaga kerja yang dilakukan oleh tenaga profesional kepelatihan dalam satuan waktu yang bertujuan untuk meningkatkan kemampuan kerja peserta dalam bidang pekerjaan tertentu guna meningkatkan efektivitas dan Kinerjadalam suatu organisasi. Yoder yang dikutip dalam Mangkunegara (2008:43) menggunakan istilah pelatihan untuk pegawai pelaksana dan pengawas, sedangkan istilah pengembangan ditujukan untuk pegawai tingkat manajemen. Istilah yang dikemukakan Yoder ini adalah rank and file training, supervisor training, dan management development. Flippo juga dikutip dalam Mangkunegara (2008:43) menggunakan istilah pelatihan untuk pegawai pelaksana dan pengembangan untuk tingkat pemimpin. Istilah-istilah yang dikemukakan olehnya adalah training operatif personal, dan executive development.

Wexley dan Yukl dalam Mangkunegara (2008:43) mengemukakan bahwa "Training and development are term is referring to planned efforts designed facilitate the acquicition of relevant skills, knowledge and attitudes by organization members". Selanjutnya Wexley dan Yukl menjelaskan pula bahwa "Development focuses more on improving the decision making and human relations skills and the presentation of a more 
factual and narrow subject matter". Pendapat ini lebih memperjelas mengenai penggunaan istilah pelatihan dan pengembangan. Mereka berpendapat bahwa pelatihan dan pengembangan merupakan istilah-istilah yang berhubungan dengan usaha-usaha berencana yang diselenggarakan untuk mencapai penguasaan skill, pengetahuan dan sikap-sikap pegawai atau anggota organisasi. Pengembangan lebih difokuskan pada peningkatan kemampuan dalam pengambilan keputusan dan memperluas hubungan manusia (human relation) bagi manajemen tingkat atas dan menengah, sedangkan pelatihan dimaksudkan untuk pegawai tingkat bawah (pelaksana).

Selanjutnya, Sikula dalam Mangkunegara (2008:44) mengemukakan bahwa "Training is short-term educational process utilizing a systematic and organized procedure by which non-managerial personal learn technical knowledge and skills for a definite purpose. Development, in reference to staffing and personal matter, is a long - term educational process utilizing a systematic and organized procedure by which managerial personal learn conceptual and theoritical knowledge for general purposes. Berdasarkan pendapat Andrew E. Sikula dapat dikemukakan bahwa pelatihan (training) adalah suatu proses pendidikan jangka pendek yang mempergunakan prosedur sistematis dan terorganisir dimana pegawai non managerial mempelajari pengetahuan dan keterampilan teknis dalam tujuan terbatas. Pengembangan merupakan suatu proses pendidikan jangka panjang yang mempergunakan prosedur sistematis dan terorganisir dimana pegawai managerial mempelajari pengetahuan konseptual dan teoritis guna mencapai tujuan yang umum. Dengan demikian, istilah pelatihan ditujukan kepada pegawai pelaksana dalam rangka menigkatkan pengetahuan dan keterampilan teknis, sedangkan pengembangan diperuntukkan bagi pegawai tingkat manajerial dalam rangka meningkatkan kemampuan konseptual, kemampuan dalam pengambilan keputusan, dan memperluas human relation.

\section{PEMBAHASAN}

Sheal (2003) dikutip dalam Triton (2009:102) menyebutkan adanya empat alasan utama mengapa pelatihan dan pengembangan staf sekarang menjadi semakin penting : (1) Perubahan-perubahan yang cepat dalam teknologi serta tugas-tugas yang dilakukan oleh orang-orang; (2) Kurangnya keterampilan langsung dan keterampilan-keterampilan jangka panjang; (3) Perubahan-perubahan dalam harapan-harapan dan komposisi angkatan kerja; dan (4) Kompetisi dan tekanan-tekanan pasar demi peningkatan-peningkatan dalam kualitas produk-produk maupun jasa-jasa.

Alasan diperlukannya program pelatihan dan pengembangan dikemukakan Cormick dalam Mangkunegara (2008:46) bahwa : "An organization should commit its resources to training activity only if, in the best judgement of the managers, the training can be expected to achieve some result other then modyfying employee behaviour. It must also support some organizational and goal, such as more efficient production or distribution of goods and services, reduction or distribution of goods and services, reduction of operating costs, improved quality, or more effective personal relation. Berdasarkan pendapat Cormick tersebut bahwa suatu organisasi perlu melibatkan sumber daya (pegawainya) pada aktivitas pelatihan hanya jika hal itu merupakan keputusan terbaik dari manajer. Pelatihan diharapkan dapat mencapai hasil lain daripada memodifikasi prilaku pegawai. Hal ini juga perlu mendapat dukungan secara organisasi dan tujuan seperti produksi, distribusi barang dan pelayanan lebih efisien, menekan biaya operasi, meningkatkan kualitas dan hubungan pribadi lebih efektif.

Goldstein dan Bukton mengemukakan ada tiga analisis kebutuhan pelatihan dan pengembangan, yaitu:

a. Analisis Organisasi, menganalisis tujuan organisasi, sumber daya yang ada dan lingkungan organisasi yang sesuai dengan realita, Wexley dan Latham mengemukakan bahwa dalam menganalisis organisasi perlu memperhatikan pertanyaan "where is training and development needed and where is it likely to be succesful within an organization?". Hal ini dapat dilakukan dengan cara mengadakan survei mengenai sikap pegawai terhadap kepuasan kerja, persepsi pegawai, dan sikap pegawai dalam administrasi. Disamping itu pula, dapat menggunakan turnover, absensi, kartu pelatihan, daftar kemajuan pegawai, dan data perencanaan pegawai.

b. Analisis Job dan Tugas, Analisis job dan tugas merupakan dasar untuk mengembangkan program job training. Sebagaimana program training dimaksudkan untuk membantu pegawai meningkatkan pengetahuan, skill, dan sikap terhadap suatu pekerjaan. 
c. Analisis Pegawai, Analisis pegawai difokuskan pada identifikasi khusus kebutuhan training bagi pegawai yang bekerja pada jobnya. Kebutuhan training pegawai dapat dianalisis secara individu maupun kelompok.

- Kebutuhan individu dari pelatihan

Analisis kebutuhan individu dari pelatihan dapat dilakukan dengan cara observasi oleh supervisor, evaluasi keterampilan, kartu kontrol kualitas, dan tes keterampilan pegawai.

- Kebutuhan kelompok dari pelatihan

Kebutuhan kelompok dari pelatihan dapat diprediksi dengan pertimbangan informal dan observasi oleh supervisor maupun manajer.

Selanjutnya alasan lain dari kebutuhan pelatihan dan pengembangan adalah sebagai berikut :

a. Adanya Pegawai Baru

Pegawai-pegawai baru sangat memerlukan pelatihan orientasi. Mereka perlu memahami tujuan, aturanaturan dan pedoman kerja yang ada pada organisasi perusahaan. Begitu pula mereka perlu memahami kewajiban-kewajiban, hak dan tugasnya sesuai dengan jobnya.

b. Adanya Penemuan-penemuan Baru

Dengan kemajuan ilmu pengetahuan dan teknologi modern, banyak ditemukan peralatan-peralatan baru yang lebih canggih dari pada peralatan kantor yang digunakan sebelumnya. Pegawai-pegawai yang akan menggunakan peralatan baru tersebut perlu mendapatkan pelatihan agar dapat menggunakannya dengan sebaik-baiknya.

Adapun cara menentukan kebutuhan pelatihan dan pengembangan dapat dilakukan sebagai berikut :

a. Analisis jabatan, dengan dibuatnya standar -standar pelaksanaan kerja untuk setiap jabatan dapat ditentukan kebutuhan pelatihan maupun pengembangan.

b. Tes psikologis, dipergunakan untuk menentukan peserta pelatihan maupun pengembangan yang memenuhi persyaratan kualifikasi yang telah ditentukan. Tes psikologis mempunyai validitas tinggi dalam memprediksi kemampuan pegawai yang akan menjadi peserta pelatihan ataupun pengembangan.

c. Penyelidikan moral, dapat dipergunakan untuk menentukan kebutuhan pelatihan maupun pengembangan.Misalnya mengukur sikap moral peserta sebelum dan sesudah pelatihan.

d. Analisis kegiatan, dipergunakan untuk menentukan kesesuaian antara bidang pekerjaan peserta dengan jenis pelatihan maupun pengembangan.

Pelatihan dilakukan untuk memberikan manfaat yang sebesar-besarnya dari output yang dihasilkan. Beberapa tujuan yang dapat diharapkan dari kegiatan pelatihan adalah :

1) Untuk memberikan kesempatan bagi segenap karyawan untuk mempertahankan dan mengembangkan skill yang selama ini dimiliki karyawan ditempat kerjanya.

2) Memberikan para karyawan skill-skill baru yang sangat dibutuhkan untuk kemajuan perusahaan.

3) Meningkatkan kualitas sumber daya manusia diperusahaan.

4) Melibatkan karyawan untuk mengembangkan wacana-wacana baru yang secara konstruktif dan terencana dapat memberikan dampak positif bagi keberlanjutan dan masa depan perusahaan.

Pelatihan SDM berdasarkan tempat pelaksanaannya dapat pada dua tempat, yaitu :

1. On the job training atau pelatihan di tempat kerja. Metode utama pelatihan di tempat kerja antara lain adalah :

- Demonstrasi. Dalam demonstrasi dilakukan pemberian materi dengan cara praktek dan contoh-contoh langsung yang dilakukan oleh pemateri dalam menyelesaikan suatu pekerjaan. Pemberian materi pelatihan melalui contoh dan praktek dalam demonstrasi memungkinkan terjadinya peningkatan skill karyawan.

- Praktek langsung. Metode ini terutama dilakukan pada pelatihan yang bersifat manajerial dan pekerjaan-pekerjaan yang memerlukan profesionalitas,

- Metode mengerjakan sendiri, dengan metode ini maka karyawan akan mendapatkan materi pelatihan melakukan beberapa kesalahan yang dilakukannya semasa pelatihan, dengan tujuan utama karyawan mampu melakukan proses adaptasi lebih cepat terhadap pekerjaan yang dilakukannya maupun lingkungan kerjanya. Metode ini banyak digunakan di instansi pemerintah atau pekerjaan-pekerjaan lain yang bersifat administratif. 
- Rotasi kerja. Metode pelatihan ini dilakukan untuk meningkatkan wawasan karyawan akan pekerjaanpekerjaan pada setiap divisi pekerjaan di tempat kerjanya, dan sekaligus mengurangi kejenuhan karyawan terhadap rutinitas kerja yang monoton.

2. Off the job training atau pelatihan di luar tempat kerja. Beberapa metode dalam pelatihan di luar tempat kerja antara lain :

- Role play atau permainan peran. Jenis pelatihan ini menampilkan simulasi oleh para peserta pelatihan dengan memerankan pelaku-pelaku yang ada dalam pekerjaan di perusahaannya.

- Diskusi kelompok. Memberikan materi-materi melalui kegiatan diskusi, dimana peserta pelatihan terlibat dan berkontribusi aktif dalam proses pelatihan. Efektivitas pelatihan dengan diskusi sangat ditentukan oleh tingkat aktivitas peserta diskusi, wawasan peserta terhadap materi pelatihan, dan kemampuan fasilitator diskusi dalam memberikan feedback kepada peserta diskusi.

- Pusat pengembangan. Pelatihan dengan memanfaatkan adanya pusat pengembangan berarti karyawan mengikuti program-program pelatihan yang sebelumnya telah disusun dan diadakan oleh pusat-pusat pengembangan tersebut bekerja sama dengan instansi atau perusahaan yang membutuhkan pelatihan.

- Ceramah. Metode pelatihan dimana pemberian materi bersifat searah oleh pemberi materi kepada karyawan. Dialog dalam metode ceramah dapat dikatakan hampir tidak diperlukan.

- Selain metode-metode pelatihan tersebut, juga ada metode pelatihan karyawan di luar tempat kerja lainnya, misalnya studi kasus, permainan bisnis, pelatihan di tempat terbuka, dinamika grup, dan belajar melalui tindakan. Untuk menilai metode pelatihan, ada beberapa unsur yang sangat perlu diperhatikan, antara lain adalah :Materi program pelatihan, Efektivitas Biaya, Prinsip-prinsip Pembelajaran..

Kemampuan penyelenggara pelatihan dalam menilai dari menyeleksi metode pelatihan dengan mendasarkan pertimbangan-pertimbangan di atas diharapkan akan menjamin diperolehnya metode pelatihan yang tepat. Pemberian pelatihan yang efektif memungkinkan diperolehnya peningkatan kualitas pekerjaan, produktivitas, loyalitas dan kinerja seorang karyawan. Untuk menilai efektifitas suatu pelatihan dapat dilakukan secara umum dengan cara menggunakan pembanding dan tanpa pembanding. Penilaian efektifitas pelatihan yang sering dilakukan dewasa ini adalah penilaian efektifitas tanpa pembanding. Hal ini karena desain penilaiannya cukup sederhana dan lebih mudah untuk mengabaikan variabel-variabel kontrol atau pengganggu. Misalnya aktivitas organisasi, kompensasi, kematangan kepribadian, kondisi psikis, dan lain sebagainya.

Penilaian efektifitas pelatihan dengan tanpa pembanding artinya bahwa peserta pelatihan hanya dinilai berdasarkan nilai awal (pre test) dan nilai akhir (post test) saja. Apabila nilai post test lebih tinggi daripada nilai pre test maka dapat dinilai bahwa efektivitas hasil pelatihan cukup tinggi karena terjadi peningkatan nilai test. Selain tanpa pembanding, penilaian efektivitas pelatihan dapat dilakukan dengan menggunakan pembanding. Pada penilaian dengan pembanding, maka dapat dibandingkan selisih nilai post test dan pre test antara kelompok yang mendapatkan suatu jenis pelatihan dengan kelompok pembanding. Kelompok pembanding dapat menggunakan non peserta pelatihan atau kelompok peserta dengan metode pelatihan yang berbeda.

\section{DAFTAR PUSTAKA}

Bartlett, Kenneth R, 2001, The Ralationship Between Training and Organizational Commitment : A Study In The Health Care Field. Human Resource Development Quarterly Vol.12 No.4.

Chaudhuri, Sanghamitra,. 2011, The Relationship between Training Outsourcing and Organizational Commitment, A Dissertation Submitted To Faculty Of Graduate School Of The University Of Minnesota Devi, R,V., Shaik, Nagurvali. 2012, Evaluating training \& development effectiveness - A measurement model, Asian Journal Of Management Research, Volume 2 Issue 1

Mei, Li., Hung., 2008, Research on How Training Influences Administrative Staff Job Involvement and Organizational Commitment, The Journal of Human Resource and Adult Learning Vol. 4, Num. 2 
Pitra, Yuan Duana., 2013, Pengaruh Pelatihan, Kompetensi Dan Komitmen Organisasi Terhadap Kinerja Pegawai Balai Proteksi Tanaman Dan Perkebunan (Bpt-Bun) Di Salatiga. Jurnal Ilmiah Fakultas Ekonomi Dan Bisnis Universitas Dian Nuswantoro

Pulakos, Elaine D., 2004, Performance Management (a roadmap for developing, implementing and evaluating performance management systems, Publisher : Society For Human Resource Management Foundation (SHRM Foundation)

Punia., Kant, S., 2013, A Review Of Factors Affecting Training Effectiveness Vis-À-Vis Managerial Implications And Future Research Directions, International Journal of Advanced Research in Management and Social Sciences, Vol.2, No.1

Setiabudi, Wahyu., 2011, Analisis Pengaruh Efektivitas Pelatihan Dan Disiplin Kerja Terhadap Kinerja Pegawai (Studi Pada Operator Pelaporan Keuangan Satuan Kerja Di Lingkungan Kantor Wilayah Kementerian Agama Provinsi Kalimantan Barat), Jurnal Ilmiah Program Magister Manajemen Fakultas Ekonomi Universitas Tanjungpura

Mangkunegara, A.A. Anwar Prabu., 2005. Evaluasi Kinerja SDM. Penerbit : PT. Refika Aditama, Bandung.

Mathis, Robert L., Jackson, John H., 2006. Human Resource Management (Manajemen Sumber Daya Manusia), Edisi 10, Penerbit : Salemba Empat

Gomes, Faustino Cardoso., 2003, Manajemen Sumber Daya Manusia, Penerbit Andi OFFSET Yogykarta 